UDC 378.4.07(5+4-11+7):378.091.217

DOI: $10.15673 /$ fie.v11i4.1551

\author{
Okulicz-Kozaryn W. \\ dr. hab., Master of Business Administration, Head of Group \\ East European Research Group \\ Okólna 107, Czestochowa, 42218 Poland \\ E-mail:okwalery@gmail.com \\ ORCID ID: 0000-0001-6486-1369 \\ Kalaman 0. \\ Ph. D., Associate Professor \\ Department of Management and Logistics \\ Odessa National Academy of Food Technologies \\ Kanatna str., 112, Odesa, Ukraine, 65039 \\ E-mail: kalaman.olga@gmail.com \\ ORCID ID: 0000-0001-5586-7654
}

\title{
HOW TO MANAGE UNIVERSITIES IN ASIA, EAST EUROPE AND NORTH AMERICA BASED ON THE PREFERENCES OF STUDENTS?
}

The goal of the study was to compare preferences of students at lectures at universities in Asia, East Europe and North America. The study used specific information, sociological and statistical research methods. Answers have been found to two practical and scientific questions after comparing students preferences:

- in what of teaching methods at lectures to invest: in auditory or visual?

- how to manage universities based on the preferences of students?

The results of statistical analysis are highly statistically significant. The goal of the follow-up research is to continue the study of how they manage at North American universities. The analysis of scientific sources showed that the methods of auditory learning dominate in didactics (theory of learning). A large number of scientific sources have shown that it is possible to consider students as Clients. Therefore, the management of universities should be focused on the needs and preferences of students. Finally, the third part of the publications showed that Eastern European students do not prefer the auditory method of teaching at lectures. And we remember, the analysis of information sources showed that the auditory method of learning dominates the theory of learning.

Key words: management, university, preferences of students, managerial decision, auditory teaching method, visual teaching method, investment.

This work is licensed under a Creative Commons Attribution 4.0 International License http://creativecommons.org/licenses/by/4.0/

Statement of the problem and its connection with important scientific and practical tasks. Our research was carried out due to new contradictions in the educational space. Since the inception of the first universities, the auditory method of teaching has ruled at the lectures. Modern methods of mass communication entered the life of students. And they get most of the information in a visual way.

The goal of the study was to compare preferences of students at lectures at universities in Asia, East Europe and North America. This goal stems from a purely practical economic issue: «In what of teaching methods at lectures to invest: in auditory or visual?». On the other hand, our goal is scientific. It relates to the management system and answers the question: «How to manage universities based on the preferences of students?».

The analysis of the latest publications on the problems. More than 80 scientific sources were studied, including those published in the journals: European Jour- nal of Contemporary Education, European Journal of Economics and Development, European Journal of Higher Education, Family Pedagogy, Food Industry Economics, Higher Education, Higher Education in Europe, Higher Education Pedagogies, International Journal for Academic Development, International Journal of Education and Practice, International Journal of Humanities and Natural Sciences, Journal of Economy and Business, Journal of Higher Education Policy and Management, Journal of Marketing for Higher Education, ManagementEducation-Science \& Society Technology-Economics Journal, Polish Journal of Management Studies, Research in Higher Education, Scientific Journal Virtus, Studies in Higher Education, Universal Journal of Educational Research, Zeszyty Naukowe Wydziału Nauk Ekonomicznych, Zeszyty Naukowe WSES w Ostrołęce, etc. The materials of conferences in Asia, Europe and America 
were also analyzed.

The publications that are the closest to the topic of the study were selected for a thorough analysis later [1; $2 ; 3 ; 4 ;$ etc.]. The analysis of scientific sources showed that the methods of auditory learning dominate in didactics (theory of learning) [5; 6; etc.]. A large number of scientific sources have shown that it is possible to consider students as Clients [7; 8; etc.]. Therefore, the management of universities should be focused on the needs and preferences of students. Finally, the third part of the publications [9; 10; etc.] showed that Eastern European students do not prefer the auditory method of teaching at lectures. And we remember, the analysis of information sources showed that the auditory method of learning dominates the theory of learning.

After the analysis of the latest publications on the problem the goal of the review was formulated.
Forming of the aims of the research. It is very important to know how to manage universities in order to meet the preferences of students. at lecture.

The object of the research is educational services

The subject of the research is the preferences of students at a lectures.

The study covered one country in Asia (Kazakhstan), two countries in East Europe (Croatia and Ukraine), two countries in North America (Mexico and the USA) from January 2018 to September 2019. Several groups of students in the above-mentioned countries were selected as the object of the study.

The main research methods were literature review, survey and statistical processing of survey results [11]. Six groups of students were interviewed (table 1).

Table 1

Characteristics of the respondents *

\begin{tabular}{|c|c|c|c|c|}
\hline № & Speciality of the respondents & Number & $\begin{array}{l}\text { Form of } \\
\text { training }\end{array}$ & University \\
\hline \multicolumn{5}{|c|}{ Asia } \\
\hline 1 & Pedagogy and psychology, bachelor study & 11 & full-time & \multirow{2}{*}{$\begin{array}{l}\text { Baishev University, Aktobe, } \\
\text { Kazakhstan }\end{array}$} \\
\hline 2 & Translation business, bachelor study & 10 & full-time & \\
\hline & in total: & 21 & - & - \\
\hline \multicolumn{5}{|c|}{ East Europe } \\
\hline 3 & Accounting and audit, bachelor study & 10 & full-time & $\begin{array}{l}\text { Odessa national Academy of } \\
\text { food technologies, Ukraine }\end{array}$ \\
\hline 4 & Project management, bachelor study & 18 & full-time & University in Split, Croatia \\
\hline & in total: & 28 & - & - \\
\hline \multicolumn{5}{|c|}{ North America } \\
\hline 5 & $\begin{array}{l}\text { Environmental and ecological economics, master } \\
\text { study }\end{array}$ & 6 & full-time & $\begin{array}{c}\text { Universidad Veracruzana, } \\
\text { Mexico }\end{array}$ \\
\hline \multirow[t]{3}{*}{6} & Engineering science, bachelor study & 4 & full-time & $\begin{array}{l}\text { County College of Morris, the } \\
\text { USA }\end{array}$ \\
\hline & in total: & 10 & - & - \\
\hline & in the sum: & 59 & - & - \\
\hline
\end{tabular}

* own survey, [12] and [13]

Thus, there were 59 respondents who took part in the survey. There are 6 groups of respondents. The main question discussed in the paper was:

- What way of learning at lectures do I prefer?

There were three possible answers:

1. The teacher gives a presentation, and I write with a slide show.

2. The teacher slowly dictates, and I write.

3 . The teacher quickly says, and I write.

The first answer refers to the visual way of learning at lectures. In the paper [5] a visual way of learning in detail is shown. There are two techniques of visual learning: Information lecture and Lecture-visualization. The information lecture uses an explanatory and illustrative method of presentation. The lecture-visualization reading is reduced to a coherent, detailed commenting by a teacher of the prepared visual materials, that reveal the topic of this lecture fully. These materials should ensure the systematization of the knowledge of the students, the presentation of new information, setting of problem situa- tions and possible solutions.

The second and third answers refer to the auditory way of learning at lectures. The authors are sure the auditory way of learning is not necessary to explain.

The goal of the research is to compare preferences of students at lectures at universities in Asia, East Europe and North America.

Giving an account of the main results and their substantiation. According to the results of the questionnaire processing, there are three figures showing the proportion of students who prefer the auditory method of lectures and the visual method of lectures. Figure 1 shows general results of the initial assessment of respondents' preferences (Asia). Fig.1 shows that the Asian students do not prefer the auditory lecture method of teaching at lectures. Fig. 2 shows general results of the initial assessment of respondents' preferences (East Europe). Fig. 2 shows that the East European students do not prefer the auditory lecture method of teaching at lectures. Fig. 3 shows general results of the initial assess- 
ment of respondents' preferences (North America).

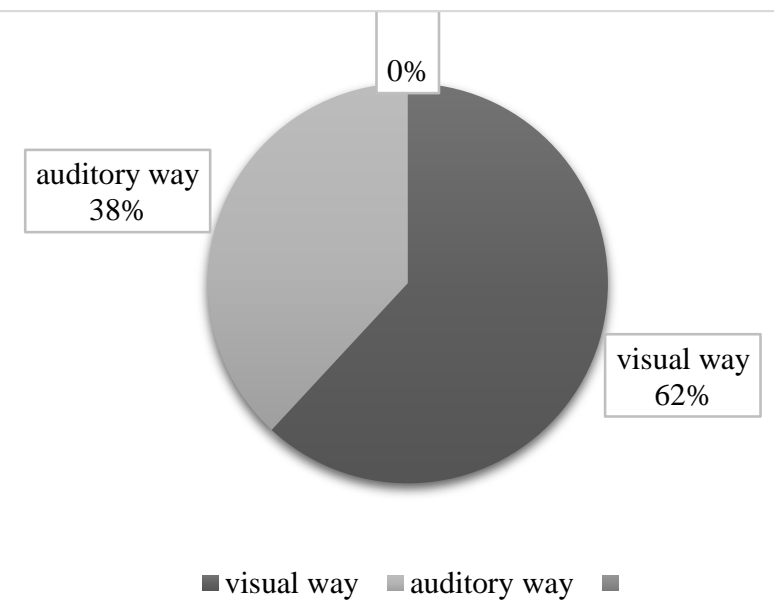

Fig. 1 - Preferences of Asian students in choosing the method of teaching at lectures, 21 respondents* * has been built on the basis of the authors' data of survey and own calculations

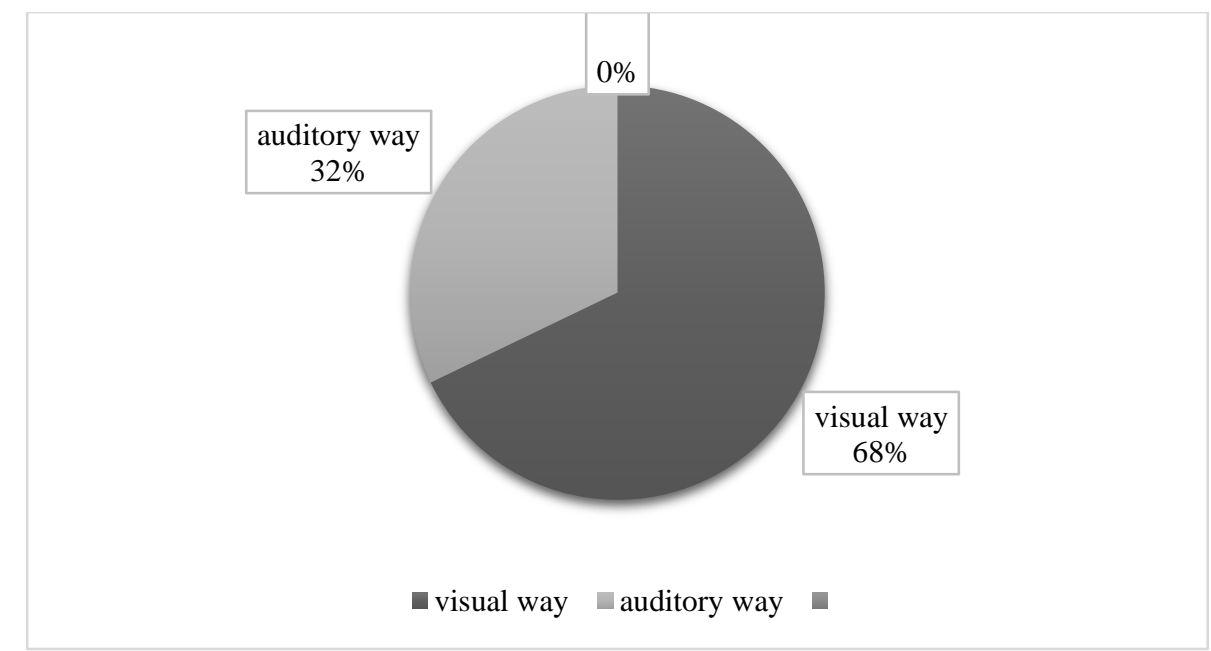

Fig. 2 - Preferences of East European students in choosing the method of teaching at lectures, 28 respondents* * has been built on the basis of the authors' data of survey and own calculations

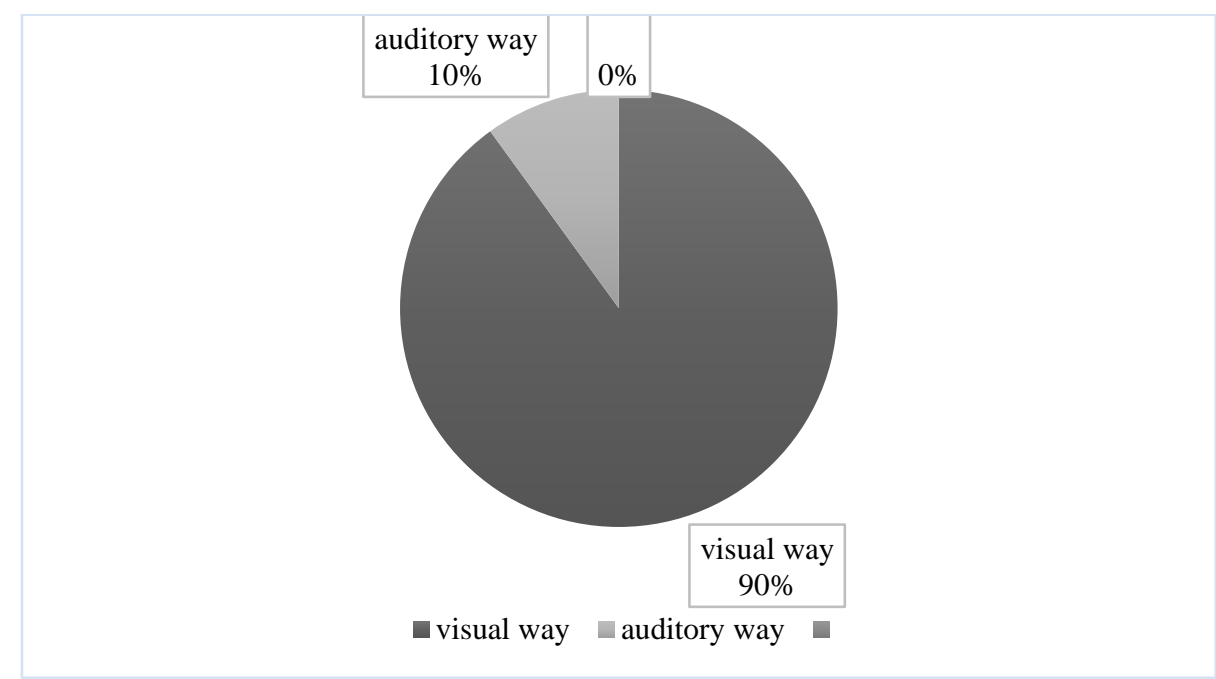

Fig.3 - Preferences of North American students in choosing the method of teaching at lectures, 10 respondents* * has been built on the basis of the authors' data of survey and own calculations 
Fig. 3 shows that the North American students do not prefer the auditory method of teaching at lectures.

Fig. 1-3 shows, that the proportion of respondents who chose the visual way of teaching at lectures ranges from $62 \%$ in Asia to $90 \%$ in North America.

The data provided in Table 2 shows the expected value, $\dot{X}$; the standard deviation for the sample, $\boldsymbol{\delta}_{\mathbf{x}}$; the standard deviation for the population, $\boldsymbol{\delta}_{\mathbf{x}-1}$ for four groups of respondents. Let $\mathrm{X}$ be a discrete random variable which takes the values $\mathrm{x}_{1}, \mathrm{x}_{2} \ldots \mathrm{x}_{\mathrm{n}}$ with respective probabilities $\mathrm{p}_{1}, \mathrm{p}_{2} \ldots \mathrm{p}_{\mathrm{n}}$ [11]. Then mathematical expectation of $\mathrm{X}$ denoted by $\mathrm{X}$ is defined as:

$$
\dot{\mathrm{X}}=\mathrm{x}_{1} \times \mathrm{p}_{1}+\mathrm{x}_{2} \times \mathrm{p}_{2}+\ldots+\mathrm{x}_{\mathrm{n}} \times \mathrm{p}_{\mathrm{n}}
$$

$$
\begin{aligned}
\boldsymbol{\delta}_{\mathrm{x}}= & \sqrt{ }\left[\left(\left(\mathrm{x}_{1}-\dot{\mathrm{X}}\right)^{2}+\left(\mathrm{x}_{2}-\dot{\mathrm{X}}\right)^{2}+\ldots+\left(\mathrm{x}_{\mathrm{n}}-\dot{\mathrm{X}}\right)^{2}\right) /(\mathrm{n}-1)\right] \\
\boldsymbol{\delta}_{\mathrm{x}-\mathbf{1}}= & \sqrt{ }\left[\left(\left(\mathrm{x}_{1}-\dot{\mathrm{X}}\right)^{2}+\left(\mathrm{x}_{2}-\dot{\mathrm{X}}\right)^{2}+\ldots+\left(\mathrm{x}_{\mathrm{n}}-\dot{\mathrm{X}}\right)^{2}\right) / \mathrm{n}\right] \\
& -\mathrm{n} \text { - the total number of data points. }
\end{aligned}
$$

After the determining the average values and the variation of the characteristics, the data were presented in the tabular form for the further analysis.

For statistical calculations, the value " 1 " was assigned to the visual lecture method of providing of educational services. The value "0" was assigned to the auditory lecture method of providing of educational services. The answers No. 2 and No. 3 of the main issue were combined for the study because they relate to the auditory lecture method of providing of educational services.

\begin{tabular}{|c|c|c|c|c|c|c|c|}
\hline \multirow[t]{2}{*}{ № } & \multirow{2}{*}{$\begin{array}{c}\text { Characteristics of the respondent } \\
\text { series }\end{array}$} & \multicolumn{3}{|c|}{ Number of choices } & \multirow[t]{2}{*}{$\dot{\mathrm{X}}_{\mathrm{i}}$} & \multirow[t]{2}{*}{$\delta_{\mathrm{x}}$} & \multirow[t]{2}{*}{$\delta_{x-1}$} \\
\hline & & Response 1 & Response 2 & Response 3 & & & \\
\hline 1 & Asia & 13 & 3 & 5 & 0,62 & 0,48 & 0,49 \\
\hline 2 & East Europe & 19 & 6 & 3 & 0,68 & 0,46 & 0,47 \\
\hline 3 & North America & 9 & 0 & 1 & 0,90 & 0,30 & 0,32 \\
\hline & The value for statistics & 1 & & & & - & \\
\hline
\end{tabular}

Table 2

Results of determining the expected value, $\dot{X}$; the standard deviation for the sample, $\delta_{x}$; the standard deviation for the population, $\delta_{\mathrm{x}-1} *$

* the results of own calculations

Table 2 shows the quantitative difference in the size of the Averages of samples for a series of Asian and East European and North American respondents. For a more detailed analysis of the significance of the difference, we turn to statistics. The difference between two mathematical expectations was estimated [14]. The data of table 2 allows to make comparisons based on the sample mean $(\dot{X})$ and on the mathematical expectation of the General population $(\mu)$.

Statistical hypotheses for two pairs of respondents will be verified below:

- first, a comparison of Asian and East European students' preferences will be executed concerning the method of teaching at lectures (series number 1 and number 2),

- then, a comparison of Asian and North American students' preferences will be executed concerning the method of teaching at lectures (series number 1 and number 3),

- and finally, a comparison of East European and North American students' preferences will be executed concerning the method of teaching at lectures (series number 2 and number 3 ),

The Research hypothesis: there are no significant differences between two independent samples.

The Research hypothesis is $\mathrm{H}_{0}: \mu_{1}-\mu_{2}=0,0$.

The Research hypothesis asserts that there are no significant differences in the students' preferences in different groups, if one does not take into account random deviations.

The Alternative hypothesis: there are significant differences between two independent samples.

The Alternative hypothesis is $\mathrm{H}_{1}: \mu_{1}-\mu_{2} \neq 0,0$.

The Alternative hypothesis asserts that there are significant differences in the students' preferences in different groups, if one does not take into account random deviations.

For the standard significance level of $99,0 \%(\mathrm{p}=$ $0,01), \mathrm{z}_{\mathrm{tabl}}=2,58[14]$.

\begin{tabular}{|c|c|c|c|}
\hline \multirow[t]{2}{*}{ № } & \multirow[t]{2}{*}{ Indicator } & \multicolumn{2}{|c|}{ Series number } \\
\hline & & 1 & 2 \\
\hline 1 & the size of a sample, $n$ & 21 & 28 \\
\hline 2 & the expected value, $\dot{X}$ & 0,62 & 0,68 \\
\hline 3 & $\dot{\mathrm{X}}_{1}-\dot{\mathrm{X}}_{2}$ & \multicolumn{2}{|c|}{0,06} \\
\hline 4 & $\mu_{1}-\mu_{2}$ & \multicolumn{2}{|c|}{0,00} \\
\hline 5 & the standard deviation for the sample, $\boldsymbol{\delta}_{\mathbf{x}}$ & 0,48 & 0,46 \\
\hline 6 & average error, $\dot{\mathrm{S}}_{\dot{\mathrm{X}}}=\boldsymbol{\delta}_{\mathbf{x}} / \sqrt{\mathrm{n}}$ & 0,105 & 0,087 \\
\hline 7 & $\dot{\mathrm{S}}^{2}$ & 0,011 & 0,008 \\
\hline 8 & $\dot{\mathrm{S}}_{1}{ }^{2}-\dot{\mathrm{S}}_{2}{ }^{2}$ & \multicolumn{2}{|c|}{0,003} \\
\hline
\end{tabular}

Table 3 presents the calculation results for series 1 and series 2 .

Data to verification of statistical hypotheses* 


\begin{tabular}{|l|l|c|}
\hline 9 & $\sqrt{\left(\dot{\mathrm{S}}_{1}{ }^{2}-\dot{\mathrm{S}}_{2}{ }^{2}\right)}$ & 0,055 \\
\hline 10 & $\left|\mathrm{z}_{\text {stat }}\right|=\mathrm{z}=\left[\left(\dot{\mathrm{X}}_{1}-\dot{\mathrm{X}}_{2}\right)-0,00\right] / \sqrt{ }\left(\dot{\mathrm{S}}_{1}{ }^{2}-\dot{\mathrm{S}}_{2}{ }^{2}\right)$ & 1,091 \\
\hline 11 & the value $\mathrm{z}_{\text {tabl }}$ for the level of significance 99,0 & 2,58 \\
\hline 12 & Result, $\mathrm{z}_{\text {stat }}<\mathrm{z}_{\text {table }}$ & Yes \\
\hline
\end{tabular}

$*$ the results of own calculations

In our case, $\left|z_{\text {stat }}\right|=1,091$. Since $z_{\text {tabl }}$ is higher than $\left|z_{\text {stat }}\right|$, then the Research hypothesis is accepted: there are no statistically significant differences between two independent samples, if one does not take into account random deviations.

For Asian and East European students there are no statistically significant differences in preferences con- cerning the method of teaching at lectures. So, the difference in the preferences of Asian and East European students, concerning the method of teaching at lectures, is not fundamental, qualitative. The difference must not be taken into account.

Table 4 presents the calculation results for series 1 and series 3 .

\section{Data to verification of statistical hypotheses*}

\begin{tabular}{|c|c|c|c|}
\hline \multirow{2}{*}{ № } & \multirow{2}{*}{ Indicator } & \multicolumn{2}{|c|}{ Series number } \\
\hline & & 1 & 3 \\
\hline 1 & the size of a sample, $n$ & 21 & 10 \\
\hline 2 & the expected value, $\dot{X}$ & 0,62 & 0,90 \\
\hline 3 & $\dot{\mathrm{X}}_{1}-\dot{\mathrm{X}}_{2}$ & \multicolumn{2}{|c|}{0,28} \\
\hline 4 & $\mu_{1}-\mu_{2}$ & \multicolumn{2}{|c|}{0,00} \\
\hline 5 & the standard deviation for the sample, $\boldsymbol{\delta}_{\mathbf{x}}$ & 0,48 & 0,30 \\
\hline 6 & average error, $\dot{\mathrm{S}}_{\dot{\mathrm{X}}}=\boldsymbol{\delta}_{\mathbf{x}} / \sqrt{\mathrm{n}}$ & 0,105 & 0,095 \\
\hline 7 & $\dot{\mathrm{S}}^{2}$ & 0,011 & 0,009 \\
\hline 8 & $\dot{\mathrm{S}}_{1}^{2}-\dot{\mathrm{S}}_{2}^{2}$ & \multicolumn{2}{|c|}{0,002} \\
\hline 9 & $\sqrt{\left(\dot{S}_{1}^{2}-\dot{S}_{2}{ }^{2}\right)}$ & \multicolumn{2}{|c|}{0,045} \\
\hline 10 & $\left|\mathrm{z}_{\mathrm{stat}}\right|=\mathrm{z}=\left[\left(\dot{\mathrm{X}}_{1}-\dot{\mathrm{X}}_{2}\right)-0,00\right] / \sqrt{\left(\dot{\mathrm{S}}_{1}{ }^{2}-\dot{\mathrm{S}}_{2}{ }^{2}\right)}$ & \multicolumn{2}{|c|}{6,222} \\
\hline 11 & the value $\mathrm{z}_{\mathrm{tabl}}$ for the level of significance 99,0 & \multicolumn{2}{|c|}{2,58} \\
\hline 12 & Result, $\mathrm{z}_{\text {stat }}<\mathrm{z}_{\text {table }}$ & \multicolumn{2}{|c|}{ No } \\
\hline
\end{tabular}

$*$ the results of own calculations

In our case, $\left|z_{\text {stat }}\right|=6,222$. Since $z_{\text {tabl }}$ is higher than $\left|z_{\text {stat }}\right|$, then the Alternative hypothesis is accepted: there are statistically significant differences between two independent samples, if one does not take into account random deviations.

For Asian and North American students there are statistically significant differences in preferences con- cerning the method of teaching at lectures. So, the difference in the preferences of Asian and North American students, concerning the method of teaching at lectures, is fundamental, qualitative. The difference must be taken into account.

Table 5 presents the calculation results for series 2 and series 3 .

Table 5

Data to verification of statistical hypotheses

\begin{tabular}{|c|c|c|c|}
\hline \multirow[t]{2}{*}{ № } & \multirow[t]{2}{*}{ Indicator } & \multicolumn{2}{|c|}{ Series number } \\
\hline & & 2 & 3 \\
\hline 1 & the size of a sample, $n$ & 28 & 10 \\
\hline 2 & the expected value, $\dot{X}$ & 0,68 & 0,90 \\
\hline 3 & $\dot{\mathrm{X}}_{1}-\dot{\mathrm{X}}_{2}$ & \multicolumn{2}{|c|}{0,32} \\
\hline 4 & $\mu_{1}-\mu_{2}$ & \multicolumn{2}{|c|}{0,00} \\
\hline 5 & the standard deviation for the sample, $\boldsymbol{\delta}_{\mathbf{x}}$ & 0,46 & 0,30 \\
\hline 6 & average error, $\dot{\mathrm{S}}_{\dot{X}}=\boldsymbol{\delta}_{\mathbf{x}} / \sqrt{n}$ & 0,087 & 0,095 \\
\hline 7 & $\dot{\mathrm{S}}^{2}$ & 0,008 & 0,009 \\
\hline 8 & $\dot{\mathrm{S}}_{1}^{2}-\dot{\mathrm{S}}_{2}{ }^{2}$ & \multicolumn{2}{|c|}{0,001} \\
\hline 9 & $\sqrt{\left(\dot{\mathrm{S}}_{1}^{2}-\dot{\mathrm{S}}_{2}^{2}\right)}$ & \multicolumn{2}{|c|}{0,032} \\
\hline 10 & $\left|\mathrm{z}_{\text {stat }}\right|=\mathrm{z}=\left[\left(\dot{\mathrm{X}}_{1}-\dot{\mathrm{X}}_{2}\right)-0,00\right] / \sqrt{ }\left(\dot{\mathrm{S}}_{1}^{2}-\dot{\mathrm{S}}_{2}^{2}\right)$ & \multicolumn{2}{|c|}{10,000} \\
\hline 11 & the value $\mathrm{z}_{\mathrm{tabl}}$ for the level of significance 99,0 & \multicolumn{2}{|c|}{2,58} \\
\hline 12 & Result, $\mathrm{z}_{\text {stat }}<\mathrm{Z}_{\text {table }}$ & \multicolumn{2}{|c|}{ No } \\
\hline
\end{tabular}

$*$ the results of own calculations 
In our case, $\left|z_{\text {stat }}\right|=10,000$. Since $z_{\text {tabl }}$ is higher than $\left|z_{\text {stat }}\right|$, then the Alternative hypothesis is accepted: there are statistically significant differences between two independent samples, if one does not take into account random deviations.

For East European and North American students there are statistically significant differences in preferences concerning the method of teaching at lectures. So, the difference in the preferences of East European and North American students, concerning the method of teaching at lectures, is fundamental, qualitative. The difference must be taken into account.

In this study, the opinions of independent respondents are transformed into strong scientific facts. We cannot consider the results obtained as a new scientific law, a new scientific regularity or a new scientific trend. We can be sure to take the results as a new scientific fact.

This new scientific fact should be taken into account in the process of finding an answer to a research question: How to manage universities in Asia, East Europe and North America based on the preferences of students?

In the process of finding we have seen:

- For Asian and East European students there are no statistically significant differences in preferences concerning the method of teaching at lectures.

- For Asian and North American students there are statistically significant differences in preferences concerning the method of teaching at lectures.

- For East European and North American students there are statistically significant differences in preferences concerning the method of teaching at lectures.

We can draw two conclusions based on the results of the statistics:

1. Management in Asian and Eastern European universities based on student preferences at lectures may be the same.

2. Management in Asian and Eastern European universities based on student preferences at lectures should be absolutely different in comparison with management at North American universities.

It's time to answer the practical and scientific questions of our research. In the first case, it is a change in the goals of investing in higher education. In the second case, management is possible through managerial decisions.

The authors had analyzed all possible ways of university management through managerial decisions. In our case, the authors consider the following ones to be the most effective and real. It is necessary:

- to develop effective methods for the visual method of teaching,

- to equip all lecture halls with tools for visual teaching methods at lectures,

- to train university lecturers to use visual teaching methods in lectures.

And finally, may be it is a good idea to separate training of students who prefer auditory and visual meth- ods of teaching at lectures.

In the practical part of management of the higher education system it is necessary to redirect investment flows to the following goals:

- the theoretical foundations of the visual method of teaching at lectures,

- the technical equipment of lecture halls,

ties.

- the retraining of the teaching staff of universi-

The results of the study can be considered as a reason for discussion. Is it a lot or a little, to poll 59 respondents?

For example, in the paper of [15], 50 managers were only interviewed. We see in the paper [16] that there were 48 respondents. In the paper [17], 28 nurses were purposely selected and interviewed. And, in the research [18] the research was carried out with the participation of 15 university students only. So, we can be sure that 59 respondents are enough to get the reliable results in our study.

Are we sure of the results of our study?

At the stage of verification of statistical hypotheses, the results are highly statistically significant $(99,0 \%)$. The result indicates that the decision will be correct in about $99,0 \%$ of cases and wrong only in 1,0\% of cases. In this sense, we have a decision-making process with accurate, controlled probability. The theory of statistics gives no reason to doubt the correctness of our results [19].

Conclusions and prospects of the further investigations. The goal of the study was achieved - we have compared preferences of students at lectures at universities in Asia, East Europe and North America.

The results of the study have showed:

1 . We should manage the higher education system across four paths at least:

- it is necessary to develop effective methods for the visual method of teaching,

- it is necessary to equip all lecture halls with tools for visual teaching methods at lectures,

- it is necessary to train university lecturers to use visual teaching methods in lectures,

- and finally, may be it is a good idea to separate training of students who prefers auditory and visual methods of teaching at lectures.

2. Funds should be invested in visual teaching methods, including:

- in the development of the theoretical foundations of the visual method of teaching at lectures,

- in the technical equipment of lecture halls,

- in the retraining of the teaching staff of universities.

3. Management at Asian and Eastern European universities based on student preferences at lectures should differ from management at North American universities.

4. The goal of the follow-up research is to continue the study of managing at North American universities.

\section{References}

1. Wende, M. C. (2003). Globalisation and Access to Higher Education. Journal of Studies in International Education, 2(7), 193-206. doi: 10.1177/1028315303007002006 
2. Uddin, J. A. (2015). Managing Strategies for Higher Education Institutions in the UK: An Overview. Higher Education for the Future, 1(2), 32-48. doi: 10.1177/2347631114558189

3. Jain, K. K., \& Agarwal, S. (2006). Higher Education in Future. Paradigm, 2(10), 25-32. doi: $10.1177 / 0971890720060205$

4. Zuberu, M. B. (2019). Choice of Learning Styles among Tertiary Students in the Tamale Metropolis. Universal Journal of Educational Research, 6(7), 1347-1355. doi: 10.13189/ujer.2019.070602

5. Okulich-kazarin, V. (2019). Lecture method preferences, auditory or visual, of Ukrainian consumers of educational services: a statistical analysis. International Journal of Education and Practice, 2(7), 54-65.

6. Slastenin, V., Isaev, I., \& Mishchenko, A. (2000). Pedagogy: textbook for students of pedagogical educational institutions. Moscow: School Press.

7. Morrison, A. (2017). The Responsibilized Consumer: Neoliberalism and English Higher Education Policy. Cultural Studies. Critical Methodologies, 3(17), 197-204. doi: 10.1177/1532708616672675

8. Dora, Y. M., Kaniawati, K., \& Nurani, N. (2019). Service Quality, Student Satisfaction and Decision in Remaining Active to Study - Study at Private Universities in West Java. Universal Journal of Educational Research, 5a(7), 18-23. doi: 10.13189/ujer.2019.071504

9. Okulich-kazarin, V. (2019). Three Scientific Facts about Ukrainian and Polish Law-students: Verification of statistical hypotheses about their Preferences of Learning at Lecture. European Journal of Contemporary Education, 3(8), 562-573. doi: 10.13187/ejced.2019.3.562

10. Okulich-kazarin, V., \& Lapitskaya, O. (2018). Higher education as a business: should Belarusian Universities change the way of teaching at lectures?. Journal of Economy and Business, 2(5), 05-10.

11. Kingston University. (2009). BUS_9641_Business_Statistics_5M: lecture notes for the Program "Masters of Business Administration». New York.

12. Okulicz-kozaryn, V., Kussanova, B., \& Yerniyazova, Z. (2019). On the possibility of higher education management in Kazakhstan based on the preferences of consumers of educational services. International Journal of Humanities and Natural Sciences, 1(8), 106-114.

13. Okulicz-kozaryn, V. (2019). Priorities of consumers of educational services at lectures at universities in Asia, Europe and North America. In Ekonomichni ta sotsialni aspekty rozvytku Ukrainy na pochatku XXI stolittia: materialy VII Mizhnarodnoi naukovo-praktychnoi konferentsii 15 zhovtnia 2019 r. (pp. 158-161). Odesa.

14. Chto takoe z-otsenka? Chto takoe p-znachenie? Retrieved May 2, 2019, from https://desktop.arcgis.com/ru/arcmap/10.3/tools/spatial-statistics-toolbox/what-is-a-z-score-what-is-a-p-value.htm.

15. Guluță, M. C., \& Rusu, C. (2016). Leadership styles and managerial behavior in Romanian companies. Polish Journal of Management Studies, 2(13), 69-80. doi: 10.17512/pjms.2016.13.2.07

16. Pavlova, A. (2016). Gender asymmetry in the designations of social roles in the Russian language in terms of perception. Eastern European Review, 2(7), 211-221.

17. Shahriari, M. (2012). Perceived ethical values by Iranian nurses. Nursing Ethics, 1(19), 30-44. doi: $10.1177 / 0969733011408169$

18. Kayalar, F. (2017). The effects of Auditory Learning Strategy on Learning Skills of Language Learners (Students' Views). IOSR Journal of Humanities and Social Science (IOSR-JHSS), 10(22), 04-10.

Received 2 October 2019

Approved 15 October 2019

Окулич-Козарин В.

Available in Internet 26.12 .2019

доктор габилит. (социальных наук), профессор, степень МВA

руководитель группы

Восточноевропейская исследовательская группа

г. Ченстохова, Республика Польша

E-mail: okwalery@gmail.com

ORCID ID: 0000-0001-6486-1369

Каламан О.Б.

кандидат экономических наук, доцент

кафедра менеджмента и логистики

Одесская национальная академия пищевых технологий

ул. Канатная, 112, г. Одесса, Украина, 65039

E-mail: kalaman.olga@gmail.com

\section{КАК УПРАВЛЯТЬ УНИВЕРСИТЕТАМИ В АЗИИ, ВОСТОЧНОЙ ЕВРОПЕ И СЕВЕРНОЙ АМЕРИКЕ НА ОСНОВЕ ПРЕДПОЧТЕНИЙ СТУДЕНТОВ?}

Целью исследования является сравнение предпочтений студентов на лекциях в университетах Азии, Восточной Европы и Северной Америки. В исследовании использовались специальные информационные, социологические и статистические методы исследования. Были найдены ответы на 
два научно-практических вопроса, после сравнения предпочтений студентов:

- в какие методы обучения на лекциях инвестировать: в аудиальные или визуальные?

- как управлять университетами исходя из предпочтений студентов?

Результаты анализа являются высоко-статистически значимыми.

Анализ научных источников показал, что методы аудиального обучения доминируют в дидактике (теории обучения). Большое количество научных источников показали, что в качестве клиентов можно рассматривать студентов. Поэтому управление университетами должно быть ориентировано на потребности и предпочтения студентов. Наконец, третья часть публикаций показала, что восточноевропейские студенты не предпочитают аудиальный метод обучения на лекциях. Также, анализ источников информации показал, что аудиальный метод обучения доминирует в теории обучения. Важно понимать, как управлять университетами, чтобы соответствовать предпочтениям студентов.

Исследование охватывало одну страну в Азии (Казахстан), две страны Восточной Европы (Хорватия и Украина), две страны Северной Америки (Мексика и США) с января 2018 года по сентябрь 2019 года. Несколько групп студентов из вышеупомянутых стран были выбраны в качестве объекта исследования.

Наше исследование было проведено в связи с новыми противоречиями в образовательном пространстве. С момента основания первых университетов, аудиальный метод обучения преобладал на лекциях. Современные методы массовой коммуникации вошли в жизнь студентов. И они получают большую часть информации визуально.

Цель исследования была достигнута - были сравнены предпочтения студентов на лекциях в университетах Азии, Восточной Европе и Северной Америке. Результаты исследования показали:

1. Необходимо управлять системой высшего образования как минимум по четырем направлениям:

- разработать эфффективные методы визуального метода обучения,

- оборудовать все аудитории инструментами для визуальных методов обучения на лекциях,

- обучать преподавателей использованию визуальных методов обучения на лекциях,

- и, наконец, может быть, это хорошая идея разделить обучение студентов, предпочитающих аудиальные и визуальные методы обучения на лекциях.

2. Средства должны быть инвестированы в визуальные методы обучения, в том числе:

- в разработку теоретических основ наглядного метода обучения на лекциях,

- в техническое оснащение аудиторий,

- в переподготовку профессорско-преподавательского состава.

3. Управление в университетах Азии и Восточной Европы, основанное на предпочтениях студентов на лекциях, должно отличаться от управления в университетами Северной Америки.

4. Цель последующего исследования - продолжить изучение управления в университетах Сeверной Америки.

Ключевые слова: менеджмент, университет, предпочтения студентов, управленческое решение, методика слухового обучения, метод визуального обучения, инвестиции.

\section{Окуліч-Козарін В.}

доктор габіліт. (соціальних наук), профресор, ступінь МBA

керівник групи

Східноєвропейська дослідницька група

м. Ченстохова, Республіка Польща

E-mail: okwalery@gmail.com

ORCID ID: 0000-0001-6486-1369

Каламан О. Б.

кандидат економічних наук, доцент

кафедра менеджменту і логістики

Одеська національна академія харчових технологій

вул. Канатна, 112, м. Одеса, Україна, 65039

E-mail: kalaman.olga@ gmail.com

ORCID ID: 0000-0001-5586-7654

\section{ЯК УПРАВЛЯТИ УНІВЕРСИТЕТАМИ АЗІЇ, СХІДНОЇ ЄВРОПИ ТА ПІВНІЧНОЇ АМЕРИКИ НА ОСНОВІ ПРЕФЕРЕНЦІЙ СТУДЕНТІВ?}

Метою дослідження $€$ порівняння переваг студентів на лекціях в університетах Азії, Східної Європи та Північної Америки. У дослідженні використовувалися спеціальні інформаційні, соціологічні та статистичні методи дослідження. Були знайдені відповіді на два науково-практичних питання, після 
порівняння переваг студентів:

- в які методи навчання на лекціях інвестувати: у аудіальні або візуальні?

- як управляти університетами виходячи з переваг студентів?

Результати аналізу є високо-статистично значущими.

Аналіз наукових джерел показав, що методи аудіального навчання домінують в дидактиці (теорії навчання). Велика кількість наукових джерел показали, що в якості клієнтів можна розглядати студентів. Тому управління університетами має бути орієнтоване на потреби і переваги студентів. Нарешті, третя частина публікацій показала, що східноєвропейські студенти не вважають за краще аудіальний метод навчання на лекціях. Також, аналіз джерел інформації показав, що аудіальний метод навчання домінує в теорії навчання. Важливо розуміти, як управляти університетами, щоб відповідати перевагам студентів.

Дослідження охоплювало одну країну в Азії (Казахстан), дві країни Східної Європи (Хорватія і Україна), дві країни Північної Америки (Мексика і США) з січня 2018 року по вересень 2019 року. Кілька груп студентів з вищезазначених країн були обрані в якості об'єкта дослідження.

Наше дослідження було проведено в зв'язку з новими протиріччями в освітньому просторі. 3 моменту заснування перших університетів, аудіальний метод навчання переважав на лекціях. Сучасні методи масової комунікації увійшли в життя студентів. I вони отримують більшу частину інформації візуально.

Мета дослідження була досягнута - були зрівняні переваги студентів на лекціях в університетах Азії, Східній Європі і Північній Америці. Результати дослідження показали:

1. Необхідно керувати системою вищої освіти як мінімум по чотирьох напрямках:

- розробити ефективні методи візуального методу навчання,

- обладнати всі аудиторії інструментами для візуальних методів навчання на лекціях,

- навчати викладачів використанню візуальних методів навчання на лекціях,

- i, нарешті, може бути, гарною ідеєю розділити навчання студентів, які віддають перевагу аудіальним і візуальним методам навчання на лекціях.

2. Кошти мають бути інвестовані в візуальні методи навчання, в тому числі:

- в розробку теоретичних основ наочного методу навчання на лекціях,

- в технічне оснащення аудиторій,

- в перепідготовку професорсько-викладацького складу.

3. Управління в університетах Азії і Східної Європи, засноване на уподобаннях студентів на лекціях, має відрізнятися від управління в університетами Північної Америки. Америки

4. Мета подальшого дослідження - продовжити вивчення управління в університетах Північної

Ключові слова: менеджмент, університет, уподобання студентів, управлінське рішення, слуховий метод навчання, наочний метод навчання, інвестиції.

\section{Література}

1. Wende M. C. Globalisation and Access to Higher Education // Journal of Studies in International Education. 2003. Volume 2, Issue 7. P. 193-206. doi: 10.1177/1028315303007002006

2. Managing Strategies for Higher Education Institutions in the UK: An Overview / Uddin J. A. and others // Higher Education for the Future. 2015. Volume 1, Issue 2. P. 32-48. doi: 10.1177/2347631114558189

3. Jain K. K., Agarwal S. Higher Education in Future // Paradigm. 2006. Volume 2, Issue 10. P. 25-32. doi: $10.1177 / 0971890720060205$

4. Choice of Learning Styles among Tertiary Students in the Tamale Metropolis / Zuberu M. B. and others // Universal Journal of Educational Research. 2019. Volume 6, Issue 7. P. 1347-1355. doi: 10.13189/ujer.2019.070602

5. Lecture method preferences, auditory or visual, of Ukrainian consumers of educational services: a statistical analysis / Okulich-kazarin V. and others // International Journal of Education and Practice. 2019. Volume 2, Issue 7. P. 54-65.

6. Slastenin V., Isaev I., Mishchenko A. Pedagogy: textbook for students of pedagogical educational institutions. M: School Press, 2000. 512 p.

7. Morrison A. The Responsibilized Consumer: Neoliberalism and English Higher Education Policy. Cultural Studies // Critical Methodologies. 2017. Volume 3, Issue 17. P. 197-204. doi: 10.1177/1532708616672675

8. Dora Y. M., Kaniawati K., Nurani N. Service Quality, Student Satisfaction and Decision in Remaining Active to Study - Study at Private Universities in West Java // Universal Journal of Educational Research. 2019. Volume 5A, Issue 7. P. 18-23. doi: 10.13189/ujer.2019.071504

9. Three Scientific Facts about Ukrainian and Polish Law-students: Verification of statistical hypotheses about their Preferences of Learning at Lecture / Okulich-kazarin V. та ін. // European Journal of Contemporary Education. 2019. Volume 3, Issue 8. P. 562-573. doi: 10.13187/ejced.2019.3.562 
10. Okulich-kazarin V., Lapitskaya O. Higher education as a business: should Belarusian Universities change the way of teaching at lectures? // Journal of Economy and Business. 2018. Volume 2, Issue 5. P. 5-10.

11. BUS_9641_Business_Statistics_5M: lecture notes for the Program «Masters of Business Administration». NY: Kingston University, 2009. 106 p.

12. Okulicz-kozaryn W., Kussanova B., Yerniyazova Z. On the possibility of higher education management in Kazakhstan based on the preferences of consumers of educational services // International Journal of Humanities and Natural Sciences. 2019. Volume 1, Issue 8. P. 106-114.

13. Okulicz-kozaryn W. Priorities of consumers of educational services at lectures at universities in Asia, Europe and North America // Економічні та соціальні аспекти розвитку України на початку ХХІ століття: матеріали VII Міжнародної науково-практичної конференції 15 жовтня 2019 р. / Одеська національна академія харчових технологій. Одеса, 2019. С.158-161

14. Что такое Z-оценка? Что такое р-значение?: [інтернет-портал]. URL: https://desktop.arcgis.com/ru/arcmap/10.3/tools/spatial-statistics-toolbox/what-is-a-Z-score-what-is-a-pvalue.htm (дата звернення: 02.05.2019).

15. Guluţă M. C., Rusu C. Leadership styles and managerial behavior in Romanian companies // Polish Journal of Management Studies. 2016. Volume 2, Issue 13. P. 69-80. doi: 10.17512/pjms.2016.13.2.07

16. Pavlova A. Gender asymmetry in the designations of social roles in the Russian language in terms of perception // Eastern European Review. 2016. Volume 2, Issue 7. P. 211-221.

19. 17. Perceived ethical values by Iranian nurses / Shahriari M. та ін. // Nursing Ethics. 2012. Volume 1, Issue 19. P. 30-44. doi: 10.1177/0969733011408169

18. The effects of Auditory Learning Strategy on Learning Skills of Language Learners (Students' Views), / Kayalar F. and others // IOSR Journal of Humanities and Social Science (IOSR-JHSS). 2017. Volume 10, Issue 22. P. 4-10.

Стаття надійшла 2.10.2019

Стаття прийнята до друку 15.10.2019

Доступно в мережі Internet 26.12.2019

Цитування згідно ДСТУ 8302:2015

Okulicz-Kozaryn W., Kalaman O. How to manage universities in Asia, East Europe and North America based on the preferences of students? // Food Industry Economics. 2019. Vol.11, Issue 4. P. 88-97. doi: 10.15673/fie.v11i4.1551

Cite as APA style citation

Okulicz-Kozaryn, W., \& Kalaman, O. (2019). How to manage universities in Asia, East Europe and North America based on the preferences of students?. Food Industry Economics, 11(4), 88-97. doi: 10.15673/fie.v11i4.1551 